\title{
EDITORIAL
}

\section{FESTSCHRIFT PIERRE DE VILLIERS PIENAAR}

It is with great and singular pleasure that the South African Speech and Hearing Association dedicates this issue of the Journal to Pierre de Villiers Pienaar. Professor Pienaar, father of speech therapy and audiology in South Africa, retired from the University of Pretoria at the end of 1972 and is now Professor Emeritus of that University.

Those workers who have been associated with Professor Pienaar in the fields of speech pathology, audiology, phonetics and general linguistics are many indeed. The persons contributing to this issue were invited to do so in view of their associations with P. de V. Pienaar. Many more than are represented here have however had close links with him but the modest length of our Journal prevents the publication of more papers than this issue is carrying. Several who have had long standing contact with Professor Pienaar regret that they are unable to produce papers for this issue but at the same time express their very best wishes to him on the occasion of his retirement - these are Professors D.T. Cole, C.M. Doke, G. Paul Moore and C. Van Riper.

The following contributors to this issue are honoured to be given the opportunity to pay tribute to Pierre de Villiers Pienaar: Professor Aron, who covers the academic and professional life of P. de Villiers Pienaar, was a student in Logopedics at the University of the Witwatersrand and first worked as a clinician at the Speech, Voice and Hearing Clinic under his headship. Professor Westphal was a student in Phonetics under Professor Pienaar at the University of the Witwatersrand. Dr. S.R. Silverman of the Central Institute for the Deaf, St. Louis, U.S.A., Professor R. Luchsinger of Zurich, and Dr. P.H. Damsté of the University of Utrecht, Holland, have all had long professional contact with P. de Villiers Pienaar. Margaret Marks and Isabella Uys, senior lecturers, have both been students in Logopedics under Professor Pienaar at the University of the Witwatersrand and both worked with him at this University, Mrs Uys joining him later in the Department of Speech Science, Logopedics and Audiology, University of Pretoria. Professor Hay first joined Professor Pienaar at the University of Pretoria working in the area of electro-acoustics and audiology, and on Professor Pienaar's retirement became Head of the Department of Speech Science, Logopedics and Audiology. Professor L.W. Lanham, Head of the Department of Phonetics and General Linguistics at the University of the Witwatersrand, was a student in Phonetics under Professor Pienaar, and Dr William Kerr, a distinguished oto-laryngologist in South Africa has had professional liaison over many years in the area of voice disorders with P. de V. Pienaar.

We thank all those who contributed to this Festschrift and join them in wishing Pierre de Villiers Pienaar good health, and a contented, fruitful retirement. 